\title{
GOVERNMENTAL REGULATION OF ACCOUNTING PROCEDURE
}

\author{
By L. G. Powers, LitT.D., \\ Sometime Chief Statistician, Bureau of the Census, \\ Washington, D. C.
}

Governmental regulation of the accounting procedure of public utility enterprises is a means to an end. Like all other governmental regulation of private business accounting, it is employed to assist in enforcing governmental regulation of private business and that in turn is a part of the governmental regulation of human conduct in the interest of the common well-being. The justification of governmental regulation of the accounting procedure of any private business must, therefore, be found in the assistance which it renders in the enforcement of the governmental regulation of private business and private conduct; and that regulation must be approved or condemned by its influence or results in promoting or injuring the interests, welfare and happiness of the great majority. The other papers contained in this volume are, therefore, more fundamental than this since they deal primarily with the moral, legal and economic justification for and expediency of governmental regulation of public utilities when considered with reference to the greatest good of the greatest number. This paper is confined to a discussion of the relation of accounts and accounting to the most successful administration of business and to the enforcement of the governmental regulation of public utility and other enterprises in the interest of the community.

The governmental regulation of a public utility or other enterprise is a social experiment and, like the experiments of chemists and physicists, naturally calls for the establishment and maintenance of orderly and systematic records with reference to such experiments. The governmental regulation of the accounting procedure of a governmentally regulated enterprise is the establishment of standard records for measuring and recording the results of the social experiment involved in the regulation of the business affected. A discussion of the subject matter of this paper may, therefore, with propriety, be introduced by a brief consideration of what may be called, 
from the point of view here noted, the records of the social experiment of governmental regulation of public utility and other private business.

A just and proper regulation of any private business, however simple it may be, can be maintained only when and where it is based upon complete and accurate information relating to the business regulated. In all cases that information must be at the command of the governmental officers who have supervision of the regulation and in a nation such as the United States, governed by a democracy, it must be provided for the people generally. These requisites for the just and proper governmental regulation of a private business are, in character, essentially the same as those for the successful and honest administration of a private business by its directors or managers, or those for the efficient and economical government of a state or municipality by those in authority therein. Such administration or government can be attained only when and where complete and accurate information relating to the business of the enterprise or of the state or municipality is at the command of those in places of responsibility or authority.

An apprehension of the fact last stated early led to the use of accounts and the evolution and application of the art of accounting in public and private business. This use and evolution followed necessarily from the purpose or function of the art of accounting. That function is to provide accurate and complete statements of the condition of business and of the results of its operation, and to furnish all other information which accounts can supply for its systematic and successful administration and regulation. The development of modern civilization and the accompanying increase in wealth, with the consequent increase in the volume and complexity of commercial and governmental business, early stimulated, if they did not force, improvements and new applications of the age-old art of accounting. These improvements and applications, in turn, have justified themselves in that they have afforded the wide-awake business manager and governmental official the added information needed in the complex state of modern society for honest and successful administration. The same factors have brought about the application and use of the newer accounting forms and practices as aids in securing what the race has always striven to attain, a just and proper regulation of all business and especially the regulation 
of the business of our public utility enterprises. This has been the genesis of modern governmental regulation of the accounting procedure of many kinds of business, including that of public utility enterprises, or, in other words, the governmental use of the forms and procedure of accounting in connection with the social experiment of regulating public utilities.

The governmental regulation of public utility enterprises and the accompanying regulation of their accounting procedure have much in common with the governmental regulation of the business and accounting procedure of banking and insurance companies and other quasi trust corporations. Laws for the regulation of these corporations have long been enacted to protect, so far as laws can, the interests of the stockholders, depositors and policy-holders, from the wrongful, incompetent and careless acts of the directors and other officers and to make the officers, directors and stockholders responsible for the safekeeping of the money of the depositors and for the fulfillment of all obligations that have been assumed with reference to the policy-holders. The governmental regulation of the accounting procedure of the two kinds of business mentioned was designed to assist the honest banker and insurance man in complying with the primary regulations of his business and also to aid him, if possible, in a more successful conduct of it. It was further designed to disclose the existence of all careless, incompetent and unbusinesslike acts on the part of directors and other officers and to assist in detecting the beginnings of wrongful acts on the part of those officers.

Some of the governmental regulation of the accounting procedure of the corporations mentioned is direct but more of it is indirect. The corporations are required to make regular and systematic reports upon prescribed forms, and the ready and economical completion of accurate and trustworthy records necessitates the development and use of uniform accounting records and procedure. The accounting regulation calling for such reports is here referred to as indirect, to differentiate it from the more complete regulation which prescribes in detail the number and form of accounts to be employed and the methods to be observed in keeping each account and in summarizing the results and conditions of business as recorded in the accounts.

The governmental regulations of the business and accounting 
procedure of public utility enterprises as well as those of banks and insurance companies rest upon the established fact that the evils and losses resulting from the ignorance, incompetence and carelessness of corporation officers are greater and therefore call for more safeguards than those which result from wilful wrongdoing. The unwise and improper acts of corporation employees originating in the factors first mentioned are, however, as a rule, readily disclosed by the formal reports, now very generally required from banks and insurance companies and are beginning to be required from public utility corporations. Hence it may be said that the indirect regulation of the accounting procedure of public utility and other enterprises is designed primarily as a safeguard against the evils and losses that result from the unwise and improper acts of well-intentioned officers. With wise supervision this accounting regulation accomplishes this end and also assists in detecting some of the conditions that result from wilful wrong-doing.

To enforce the governmental regulation of public utility enterprises which forbids specific acts as well as requires certain others, and to ensure the correctness of the reports here mentioned, the governmental inspection of such reports should be accompanied by formal examinations of the accounting records of the enterprise concerned. This examination should be made by experienced and thoroughly trained examiners and accountants. Such examination is necessary to enforce the governmental regulation of the enterprise itself as well as the regulation of the accounting procedure. Furthermore, this governmental examination of accounts is made comparatively easy if the accounts are kept in a scientific and orderly manner and with sufficient detail to provide all the data for a wise, honest, economical and efficient administration. An accounting procedure which provides these data should, therefore, be among the requirements specified in statutes and other governmental regulation of public utility and other business enterprises whose activities are of a quasi trust nature. In so far as the governmental regulation of the accounting procedure of these enterprises fails to provide the data mentioned, that regulation falls short of the ideal and is inferior to that which must sometime be attained by the accounts of the honest administrator who has learned to make the largest use of accounting in the conduct of his business and has thus made accounts a handmaid of the spirit of economy and efficiency in business operation. 
The wise and complete regulation of any line of business is a social achievement that requires something more than the enactment of a single statute. That enactment, as some one has expressed it, merely establishes the condition for a social experiment. The discussion embodied in the other papers of this volume emphasizes this fact and shows how much more must be done by governments before our various public utilities will be operated in ways that will work the greatest good for the greatest number. In like manner we should recognize the fact that the wise and proper regulation of the accounting procedure of any kind of public utility enterprise is never established by a single statute, nor as the result of the effort of one man or a group of men in a short period of time. Hence in here expressing the opinion that the best accounting procedure now required from public utility enterprises in the United States is far from perfect, the writer does not wish to be understood as going further than to state that the regulation of such procedure, like the regulation of the utilities themselves, is in its earlier and thus necessarily incomplete state. Some illustrations of the slow development of fairly good regulation of the accounting procedure of banking and insurance corporations may aid in avoiding undue criticism of the present accounting procedure prescribed for our American public utility enterprises.

The state of New York early passed laws for the regulation of the business of banking which prescribed a proper accounting procedure and enforced such regulation by systematic examinations. The wrecking of a large savings bank by its officers after this accounting regulation and examination had been in force more than a generation disclosed the imperfection of that regulation and examination with respect to bank receipts and brought about changes that have proved most beneficial and for more than another generation have prevented the failure of a New York savings bank. The earlier accounting procedure, although under state supervision, did not accomplish all that the bank regulating acts had been framed to secure.

Life insurance companies were established in New York before 1850 , and the state early assumed the duty of regulating them and to that end had sought indirectly to regulate their accounting procedure by requiring specified reports. But more than a half century after the enactment of the first of these laws, the Hughes inves- 
tigation of the New York insurance companies disclosed a lamentable failure on the part of the companies to use the art of accounting in any scientific or complete way to show their success or failure, their efficiency or wastefulness of management. A half century of legislation and of effort on the part of state officials had failed to establish the proper regulation of the accounting procedure on the part of these great quasi public institutions.

The problems connected with the wise and proper regulation of the American public utilities, including our interstate, state and municipal transportation, telegraph and telephone companies and our gas and electric light and power companies, are more numerous and complex than those which, with a much earlier beginning, have been solved in the case of our banking and insurance corporations. In like manner, the problems, whose solution must be obtained before an efficient and altogether satisfactory regulation of the accounting procedure of these utilities is attained, are greater, more numerous and more complex than those met with in the case of the business undertakings mentioned.

In the case of these public utilities, the work of securing and enforcing governmental regulation of accounting procedure has been only recently attempted. It is, therefore, hardly to be expected that any accounting procedure enforced by governments with reference to these utilities will have attained the degree of perfection that has been developed with reference to lines of business whose regulation has been so much longer under governmental direction and control. Notwithstanding this fact, it is to be noted that the Interstate Commerce Commission of the United States government and the Public Service Commissions of the state of New York, and those of a few other states, have in recent years made most commendable progress in the preparation and introduction of standard accounting procedure on the part of the utilities subject to this supervision.

A comparison of the work of these governmental commissions with that of the average commercial accountant employed by the utility enterprises demonstrates the superiority of the procedure prescribed by the commissions. The commissions have, therefore, accomplished much under adverse circumstances. The imperfection of their work, and thus the distance that governmental regulation of the accounting procedure of these utilities must, even yet, ad- 
vance, before anything like ideal results are attained, may be noted by the following facts. The regulations do not call for, and no public utility corporation seeks at the present time to present, a cleancut statement of (1) the actual wealth in the possession or control of the enterprise, (2) the amount of the claims of creditors against it, or (3) the amount of the proprietary interests or property rights of its stockholders in the wealth in its possession or under its control.

The Interstate Commerce Commission in its tentative classification of general balance sheet accounts (revision of 1913) which includes a suggested form for a balance sheet has, however, taken a long step forward towards the adoption of a procedure that will secure the above described statements. In the pamphlet referred to, the commission has dropped the incorrect and misleading designation "reserves" from the titles to the accounts to which is credited the current depreciation of property and equipment which is debited to expense. Further, the commission requires that all these "offsets" which have not been balanced by expenditures for replacements shall be shown in the balance sheet on the side of assets as deductions from the book value of the property and equipment, and not on the opposite side among the liabilities and proprietary interests. This procedure is a long way in advance of the practice of the average commercial accountant and is a step towards the preparation of balance sheets that will clearly provide the three statements above mentioned.

A balance sheet prepared as directed by the Interstate Commerce Commission and as described above gives a much less exaggerated statement of the wealth under the control of the railroad than used to be prepared by all public utility enterprises since it eliminates from the aggregate of so-called assets the value of the property and equipment that has been lost or wasted by depreciation. It includes however, as assets the "offsets" to the proprietary interests of the stockholders represented by the debit balances in the three accounts to which are given the designations "unextinguished discounts on capital stock," "unamortized debt discount and expense" and "property abandoned chargeable to operating expenses."

As a rule, the amounts to be reported by railroad companies after these three titles are small but the corresponding amounts included in the balance sheets of other public utility enterprises are considerable. But small or large in amount, the ledger debits re- 
ferred to are never assets and never represent any property or wealth in the possession or control of the enterprise and hence, like the depreciation credits previously referred to, they should be shown as the Interstate Commerce Commission directs the depreciation credits as deductions from the items to which they are offsets.

But few of the commercial accountants of the past or the present in the preparation of balance sheets clearly differentiate the liabilities or claims of creditors of the enterprise from the proprietary interests or property rights of the stockholders. These liabilities and rights are both represented by credit balances in the ledger and should be shown on the same side of the balance sheet but should there be fully differentiated one from the other for reasons which have been so forcibly stated by Mr. Charles E. Sprague in his Philosophy of Accounts as follows:

1. The rights of the proprietor involve dominion over the assets and power to use them as he pleases, even to alienating them, while the creditor cannot interfere with him or them except in extraordinary circumstances.

2. The right of the creditor is limited to a definite sum which does not shrink when the assets shrink, while that of the proprietor is of an elastic value.

3. Losses, expenses, and shrinkage fall upon the proprietor alone, and profits, revenue and increase of value benefit him alone; not his creditors.

No differentiation of the claims of creditors from the rights of stockholders is prescribed for railroad balance sheets, by the Interstate Commerce Commission nor by other American public utility commissions so far as is known to the writer, and hence the balance sheets prepared in accordance with the instructions of these commissions do not make any clear-cut exhibits or statements of the creditors' claims as distinct from the stockholders' rights, and the latter are exaggerated by the amount of the three classes of offsets shown after the titles to which attention has already been called.

The latest Interstate Commerce Commission's instructions for balance sheet statements present a better classification of the credit items of the ledger than previously prescribed and a far better one than is usually shown by the balance sheets arranged by commercial accountants. The physical valuation of railroad property now begun by the Interstate Commerce Commission will naturally lead to clearer and more exact balance sheet statements along the lines that will cause a differentiation and more exact statement of the actual 
wealth of utility enterprises - the actual claims of creditors and the actual property rights of the stockholders. Such accounting information will prove of great value in the taxation of public utility enterprises, in establishing rates for the utilities furnished and in securing a better administration of the utility corporations. Under the wise and conservative leadership of the Interstate Commerce Commission and other commissions the country is making substantial and steady progress towards the adoption of an intelligent and just accounting procedure. 